\title{
Matriculation: A Program to Increase the Initial Ability of Mathematics Education Student
}

\author{
Ika Noviantari ${ }^{1}$ \\ ${ }^{1}$ Jurusan Pendidikan Matematika Universitas Borneo Tarakan \\ ika_viviantari@borneo.ac.id
}

\begin{abstract}
The initial abilities of students differ from one student to another, one of which can be caused by differences in school origins. Some students come from high schools majoring in Mathematics and Natural Sciences, Social Studies, computers, agriculture, and even culinary. The difference in students' initial abilities will certainly be a problem in terms of receiving lecture material with more complex material. This research provides an alternative way to solve the problem by holding a matriculation program. The research design was a pre-experimental single group pretest-posttest type, students who take the matriculation are given a pretest and posttest of 20 questions. Then the pretest and posttest results were compared and obtained an $\mathrm{N}$-Gain score, which aims to see improvements. The sample in this study was 72 students, with a purposive sampling technique. The results showed an increase in the average pre-test score of 30.86 from 45.25 to 76.11 . The percentage of N-Gain as much as $83.33 \%$ was included in the medium and good category so it can be concluded that effective matriculation can improve the initial ability of students majoring in mathematics education.
\end{abstract}

Keywords: matriculation, initial ability, mathematics education, difference

\section{INTRODUCTION}

Students studying in the Mathematics Education Department have different basic knowledge, especially new students. This could be because they come from high schools and even senior secondary schools with majors not only majoring in Mathematics and Natural Sciences but also from agriculture, Indonesian language, social studies, culinary, administration and others. Primary school mathematics learning in each of these majors has differences in terms of the material presented according to the curriculum. So that the initial/basic abilities of new students majoring in mathematics education will differ from one another beyond the ability to absorb basic mathematical material understanding that has been given at the previous level. Students who come from high schools with the Mathematics and Natural Sciences level are considered to have better basic abilities than students from other majors in terms of the content of basic mathematics material in the curriculum.

Matriculation material is adjusted to the basic needs required in lecture activities such as basic calculus, integer operations, and also basic geometry because the lecture material in the early semester of the mathematics education department is a continuation of basic mathematics at the secondary school level. Therefore, students' basic mathematical abilities must be equalized first, to be able to properly accept more complex materials in the courses to be studied. Equation of these basic skills, one of them is by implementing a matriculation program for new undergraduate students. This program is used to equalize perceptions, initial abilities, and basic concepts of new students as a result of implementing the different curriculum.

The mathematics education department in providing debriefing to new students before entering lectures is by providing matriculation activities. So that the matriculation is important to be carried out as one of the stages of introducing the department in which the student will study [1]. New learning experiences before starting lectures can be obtained from matriculation [2]. The implementation of the new student matriculation program in the mathematics education department at the Teaching and Education Faculty of the University of Borneo Tarakan is the first time. So, it is hoped that by 
following the matriculation program, students' initial abilities can increase according to their basic needs in learning material in lectures in the mathematics department.

\section{METHOD}

The Department of Mathematics Education, Faculty of Teacher Training and Education, University of Borneo Tarakan is the place for the implementation of this research activity, with a pre-experimental research design type of single group pretest-posttest. This type of research aims to see a cause-and-effect relationship within a group of subjects. Before being given treatment, the subject group was given a pretest and after the treatment was measured again by posttest [3]. This study provides treatment, namely the matriculation program on the sample, Then see the effect based on the results of the treatment through the post-test. The conclusions obtained were drawn from comparing the pre-test and post-test results. An overview of the pre-test and post-test results are obtained from the processing of questions by a sample of 20 questions. The collection of all measurements of something to be studied, not only a collection of people/objects, is a population. But also can see the nature and character of all samples to be studied [4].

All new students of class 2019 majoring in mathematics education were 72 students in the sample. Sampling was carried out by purposive sampling because the research is aimed at new students who will take the matriculation program. The pre-test and posttest results data were assessed and processed, the results are presented in tables and graphs. The data analysis begins with a graph of the results of the pretest and posttest. It is observed whether the value has increased by looking at the N-Gain. It was also seen that the number of students who passed the set graduation score for the matriculation program had a score greater than 69.99 .

\section{RESULTS AND DISCUSSION}

The results of the pretest and posttest of the 20 questions given to the sample are shown in Figure 1.

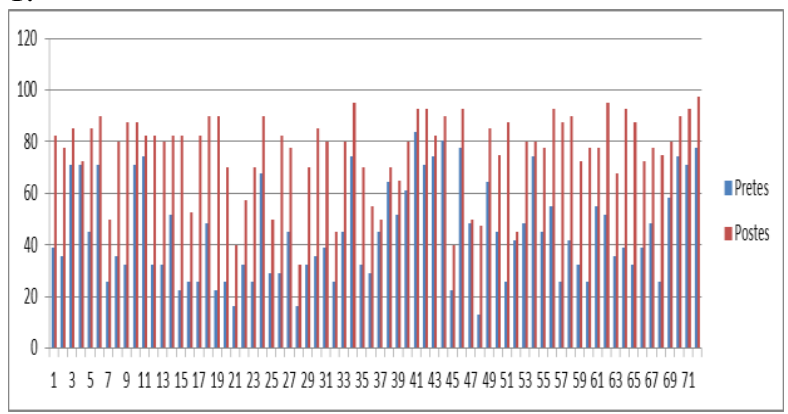

Based on Figure 1, it can be seen that all students experienced an increase in value seen from the difference between the pre-test and post-test scores. The average value of the pre-test results was 45.25, an increase of 30.86 so that in the post-test the average value was 76.11. The highest score obtained by students during the pre-test was 83.87 , while students who obtained the lowest score were 12.90. The highest increase in score was obtained by students with sample number 19, and the lowest increase in scores was obtained by students with sample number 4 obtaining the lowest score. This can be seen in the post-test score, the highest score of students is 97.50 with the lowest score obtained by students is 32.50 .

Analysis of the number of students who passed, seen from the graduation criteria of the matriculation program, namely 69.99 as many as 57 students or $79.17 \%$ who did not pass, and only 15 students passed or $20.83 \%$ if you see the pre-test results. Conversely, when viewed from the results of the posttest, 57 students graduated or $79.17 \%$, and 15 students or $20.83 \%$ who did not pass the matriculation program There was a reversal between the number of students who did not graduate and those who graduated, and the number of students who passed the matriculation program by the graduation criteria of the program has increased by 42 students. However, things that must be kept in mind are that 15 students did not pass the matriculation program because they will attend lectures in the mathematics education department with the assumption that their initial abilities are not the same as other students.

The effect of the matriculation program on increasing the initial ability of students majoring in mathematics education can be seen from the N-Gain Score. The N-Gain score value from the results comparing the pretest and posttest values is in Figure 2.

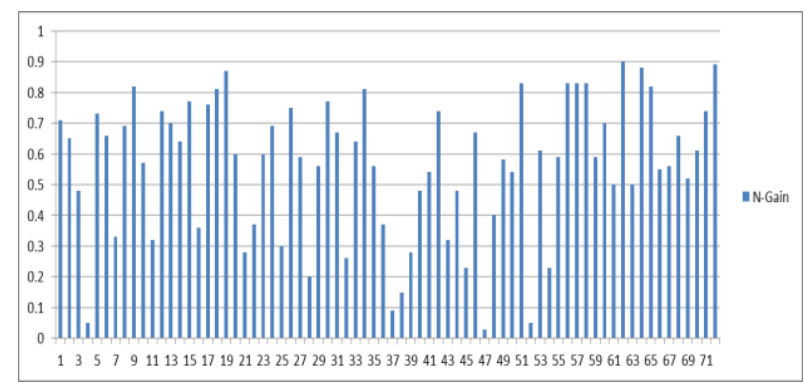

Figure 2 N-Gain SCore

The N-Gain value was categorized into 3, namely good, moderate and sufficient categories. The category results areas in the table below:

Figure 1 Value of Pretest and Posttest 
Tabel 1 Division of N-Gain Result Categories

\begin{tabular}{ccc}
\hline Kategori & Jumlah & \% \\
\hline good $>0,70)$ & 23 & 31,94 \\
\hline $0,3 \leq$ medium $<0,7$ & 37 & 51,39 \\
\hline less $<0,3$ & 12 & 16,67 \\
\hline
\end{tabular}

Based on table 1 above the results of the N-Gain categorization of $83.33 \%$ are included in the medium and good categories, so it can be concluded that the matriculation program is effective in improving students' initial abilities.

\section{CONCLUSION}

Based on data analysis and discussion, it can be concluded that the implementation of an effective matriculation program can improve the initial abilities of students in the mathematics education department of the Teaching and Education Faculty of the University of Borneo Tarakan. The matriculation program can be used as an alternative in providing an understanding of basic material before lectures. Furthermore, the matriculation program needs to be implemented every odd semester of the new academic year.

\section{AUTHORS' CONTRIBUTIONS}

This research provides benefits in making innovations in increasing the initial abilities of students in the mathematics education department. So that the results of this study can be used as a material consideration for the sustainability of the matriculation program in the mathematics education department. And it can be used as a reference for reviewing the requirements for conducting a final seminar in the mathematics education department, one of which is by requiring all students to obtain a graduation certificate for the matriculation program if they are going to submit a final seminar.

\section{ACKNOWLEDGMENTS}

I would like to express my gratitude to all parties who have played a role in the implementation of this matriculation program starting from the committee and also the speakers in the matriculation program in particular so that the results of the program implementation can be put in writing and provide information to everyone.

\section{REFERENCES}

[1] M. Hartati, "Respon Mahasiswa Mengenai Pelaksanaan Matrikulasi Bagi Mahasiswa Baru IKIP PGRI Pontianak," J. Edukasi, vol. 15, p. 243, 2017.

[2] N. Rosliana, A. Permanasari, and F. Sudargo,
"Overview Study Of Health Chemistry Matriculation At Public Health Major STIKES Dharma Husada Bandung," Math. Educ. Sci. J., vol. 2, pp. 187-194, 2014.

[3] Nursalam, Konsep dan Penerapan Metodologi Penelitian Ilmu Keperawatan, 2nd ed. Jakarta: Salemba Medika, 2008.

[4] I. Nurdin and S. Hartati, Metodologi Penelitian Sosial. Surabaya: Media Sahabat Cendekia, 2019. 